\title{
Vitae
}

Zhanna Krasnobaieva-Chorna is Doctor of Philology, Professor, Professor of Department of General and Applied Linguistics and Slavonic Philology at Vasyl' Stus Donetsk National University. Her areas of research interests include theoretical and applied aspects of phraseology and phraseography, theory of axiophraseme pragmatics, linguoculturology, linguoconceptology, linguopersonology and discourse.

Correspondence: zh.krasnobaieva@ donnu.edu.ua.

Надійшла до редакції 19 березня 2021 року Рекомендована до друку 2 квітня 2021 року

Костянтин Мізін

ORCID: orcid.org/0000-0002-5216-6032

DOI 10.31558/1815-3070.2021.41.34

УДК 811.111'25:811.161.2’25

\section{УНИКНЕННЯ ПЕРЕКЛАДАЦЬКИХ ПОМИЛОК ПРИ ВІДТВОРЕННІ АНГЛІЙСЬКОЮ МОВОЮ НАЗВ «ЧУЖИХ» ЕМОЦІЙ: КОРПУСНОБАЗОВАНА МЕТОДИКА}

У пропонованій розвідиі апробовано методику, яка дає змогу уникнути перекладацьких помилок при передачі англійською мовою назви специфічного для німецької лінгвокультури емочійного поняття «Torschlusspanik», яке може визначатися в англійській мові лексемами angst, fear, anxiety ma panic (найпоширеніший випадок - fear; angst i panic перебувають на межі статистичної похибки). Однак за допомогою опрацьованої методики встановлено, щуо це поняття має передаватися-описуватися не лексемою fеar, як ие простежується нині чи не у більшості випадків, а апхіеtу, оскільки саме остання може викликати у представників англійськомовних лінгвокультур найадекватніше уявлення про той панічний, тривожний, метафізичний вид страху, який криється за німецькою композитою Torschlusspanik.

Ключові слова: переклад, перекладачька помилка, емочія, емоційне поняття, корпуснобазована методика.

1. Постановка проблеми. Переклад галузево-специфічної термінології є тією проблемою перекладознавства, яка протягом тривалого часу не втрачає актуальності. Це стосується більшою мірою не технічних, а гуманітарних галузей, бо в точних науках і відтворення термінів є більш точною, але коли мова йде про внутрішній світ людини - психічний і духовний (моральний), то тут «перекладацькі муки» може провокувати той факт, що у вихідній мові навіть її носії часто не можуть провести чітку межу між подібними поняттями, тобто синонімічними позначеннями (термінами), які за ними криються.

Особливою мірою це стосується надзвичайно складного й дифузного емоційного світу людини, у якому остання не завжди може зорієнтуватися та точно назвати ту емоцію або той емоційний стан, які вона переживає. І якщо відтворення базових (основних) емоцій не створює особливих перешкод, оскільки такі емоції є чітко визначеними (до того ж, чи не в кожній мові, принаймні європейській, існують слова (терміни) на позначення цих емоцій), то з передачею комплексних емоцій виникають справжні «перекладацькі муки». Яскравим прикладом тут може слугувати той факт, що протягом сорока років так і не з'явилося точного перекладу українською мовою (власне, і російською) тих емоцій, які входять до відомої в науковому світі адаптаційної моделі емоцій Р. Плутчика (Plutchik 1980) «Wheel of emotions [коло емоцій]». Проблема виникла через численні терміни-синоніми комплексних емоцій, а ії̈ розв'язання ви- 
магає залучення не лише психологів, але й фахових перекладачів. Ще краще - i психолога, i фахового перекладача в одній особі, бо «наївні» перекладачі - психологи, психотерапевти, соціологи та ін. - вибирають здебільшого перше значення багатозначного слова.

«Наївний» підхід простежується, наприклад, і до перекладу самого поняття «wheel of emotions», де «коло» майже в усіх українських і російських перекладах стало «колесом», бо у двомовних словниках першим значенням англійського іменника wheel фіксується саме «колесо» (див., напр.: АУС). Однак поза увагою «наївних» перекладачів залишилися такі значення цього слова, як «коло» та «рух колом» (див. репрезентативні тлумачні словники англійської мови, напр.: NWD: 1119). Так, правильними перекладами назви збірника наукових праць за редакцією Р. Плутчика та Г. Конте «Circumplex Models of Personality and Emotions» (Plutchik, Conte 1997) можуть бути, на мою думку, два варіанти: «Циркумплексні моделі особистості та емоцій» або «Колові моделі особистості та емоцій» (пор. лат. circumplexus - «охоплення; оточення; обіймання»; circumplector - «обіймати; охоплювати; оточувати»). Але жодним чином не якісь там «колісні моделі».

Комплексні емоції - це результат динамічності емоційного світу людини, де одні емоції постійно змінюють інші, породжуючи численні комбінації взаємопереходів. Уся емоційна «мозаїка» внутрішнього світу індивіда формується навколо базових емоцій, оскільки взаємопереходи останніх створюють те підгрунтя, на якому виникають нові якості цих емоцій, які, власне, і є вторинними (складними, комбінованими), тобто комплексними емоціями (див. детальніше: Levenson 2011). Такі емоції вважають суто «людськими», оскільки вони $є$ результатом соціологізації індивіда. Унаслідок соціологізації у смисловій структурі емоційних понять виникають культурні смисли, які на рівні мови фіксуються семантичною структурою назв відповідних емоцій, оскільки вже не викликає гострих дискусій той факт, що емоції безпосередньо корелюють із когніцією людини та іiі мовою (Schwarz-Friesel 2007: 277). Дифузність комплексних емоцій, а також ті культурні смисли, які вони можуть містити, і $є$ тими перешкодами для перекладача, що породжують «перекладацькі муки».

Ще складнішим випадком є відтворення етноспецифічних емоцій, коли у перекладній (цільовій) мові взагалі відсутні лексичні відповідники (див., напр.: Мізін 2018; Mizin et al. 2019; Mizin, Ovsiienko 2020). Та й навіть при наявності в цільовій мові лексичних відповідників досить проблематичним є пошук еквівалентного терміна для тих комплексних емоцій, номінації яких розмежовуються лише одним, часто незначним, семантичним відтінком.

У випадку відсутності лексичних відповідників для позначення німецьких специфічних емоцій представники англійськомовних лінгвокультур (британці, американці, австралійці та ін.) застосовують, як правило, найпростіший прийом перекладу - калькування. Тому в англійськомовному - як науковому, так і «наївному» - дискурсі широко функціюють німецькі слова-терміни Angst, Schadenfreude, Torschlusspanik, Sehnsucht, Gemütlichkeit, Geborgenheit, Fremdscham / Fremdschämen, Gönnen, Weltschmerz, Fernweh та ін., хоча пишуться вони переважно з малої літери. Але калькування не допомагає, коли виникає необхідність розтлумачити представнику «чужої» лінгвокультури ті поняття, які криються за цими словами, тобто максимально точно описати відповідні емоції.

При описі-перекладі комплексних специфічних емоцій важливим моментом є встановлення тих лексичних відповідників, які можуть створити у свідомості носіїв цільової мови найдетальніше та найадекватніше уявлення про ці емоції. Коли такі відповідники знайдено, то їх слід доповнити інформацією, яка розкриє етнокультурну своєрідність досліджуваних емоцій. Останні можуть являти собою цілий фрагмент емоційного світу представників німецькомовних лінгвокультур (німців, австрійців, швейцарців), тому перекладачу потрібно визначити в їхній структурі передусім домінантну емоцію, яка має бути добре знайома реципієнтові перекладу, тобто правильно підібраний лексичний відповідник - назва емоції повинен викликати у свідомості носіїв цільової мови уявлення про найбільш адекватне емоційне переживання. При цьому перекладач має керуватися правилом, що емоції властиві 
людині як виду, тому емоційні переживання представників різних лінгвокультур значною мірою збігаються, а відсутність мовного позначення певної емоції в цільовій мові зовсім не означає, що ця емоція є незнайомою іiі носіям.

Перекладачі можуть ідентифікувати домінантну емоцію за допомогою детального аналізу відповідного мовного позначення, послуговуючись різноманітними словниками й довідниками, а також галузевою науковою літературою. Однак установлення значеннєвої структури слова-назви емоції не формує зазвичай повного уявлення про неї. Тому вивчення значеннєвої структури такого слова-назви слід доповнити аналізом його смислової структури. Для цього сьогодні існують широкі можливості, які надає корпусна лінгвістика, оскільки дослідити смислову структуру будь-якого слова можна на основі перекладацького аналізу його конкордансів у репрезентативних корпусах вихідної мови.

2. Мета статті. Метою пропонованого дослідження $\epsilon$ (1) виявлення перекладацьких помилок при відтворенні англійською мовою назви специфічного для німецької лінгвокультури поняття «Torschlusspanik» (мовного позначення для цієї комплексної емоції в українській мові не існує; досл. «паніка закритих воріт»; основний зміст композити Torschlusspanik: «а) страх (паніка) через брак часу; b) страх (паніка) через швидкоплинність часу; с) криза середнього віку; d) страх (паніка) не зреалізувати якість життєві / кар'єрні плани через зрілий вік» (Mizin, Letiucha 2019: 244)) та (2) опрацювання методики, за допомогою якої можна уникнути таких помилок. Ця методика передбачає застосування даних мовних корпусів (частотність, коокуренції, конкорданси).

3. Матеріал і методика дослідження. Основна функція сучасного перекладача - це не просто автоматична заміна мовних одиниць і конструкцій вихідної мови відповідниками цільової мови. Перекладач - це передусім дослідник, який добре орієнтується не лише в царині перекладознавства, але й суміжних наукових дисциплін - лінгвістики, літературознавства, психології, філософії, антропології, культурології та ін. Що ж стосується тих труднощів, із якими перекладач зіштовхується, відтворюючи емоції, то тут існують, як мінімум, три випадки, коли перекладачу необхідно підкріпити правильність вибору відповідника (словаеквівалента) цільової мови науково обгрунтованими висновками:

1) якщо є сумніви щодо точності в цільовій мові того лексичного відповідника певного емоційного поняття, який зафіксовано у двомовних словниках;

2) коли лексичні відповідники відсутні у словниках узагалі;

3) якщо відсутні не лише словникові відповідники, але й саме емоційне поняття є нерелевантним (нетиповим) для цільової лінгвокультури.

У перелічених випадках слушною, на мій погляд, є верифікація наукових (енциклопедичних) даних про емоційне поняття «наївними», щоб досягти більшої об'єктивності вибору лексичного відповідника в цільовій мові або, принаймні, точніше описати (передати) це поняття. Наукові дані - це не лише різноманітні словники та довідники, але й результати досліджень із галузі психології, психолінгвістики, когнітивної психології, когнітивної лінгвістики та культурної лінгвістики. Наукові дані протиставляються «наївним», оскільки останні отримують, як правило, за допомогою тих джерел, методів і підходів, які вважаються не зовсім науково об'єктивними, бо всі вони спрямовані на роботу із суб'єктом - носієм мови («ненаукова» інтуїція, «не зовсім наукова» інтроспекція, спонтанне мовлення і под.).

Методики отримання інформації від респондентів постійно удосконалюються (опитування, асоціативні експерименти тощо), але ще й досі вони демонструють низку слабких місць у методологічному плані. Тому останнім часом із цією метою все частіше використовуються дані мовних корпусів, бо методологія корпусної лінгвістики вважається більш надійною та перспективною, ніж опитування респондентів або психолінгвістичні експерименти (зрозуміло, що мова не йде про такі сучасні науково надійні експериментальні методики, які, наприклад, передбачають залучення магнітно-резонансної томографії для вивчення реакції зон головного мозку на різні стимули). 
3 огляду на це методика пропонованого дослідження грунтується на трьох кроках:

1) ідентифікації перекладацьких помилок при передачі німецького специфічного емоційного поняття «Torschlusspanik» англійською мовою;

2) корекції цих помилок на основі наукових даних;

3) верифікації наукових даних «наївними» для досягнення максимальної наукової об'єктивності. Із цією метою залучаються дані репрезентативних корпусів British National Corpus (BNC), Corpora Collection of University Leipzig (CCUL) та Digitales Wörterbuch der deutschen Sprache (DWDS), а також здійснюється перекладацький аналіз фрагментів конкордансів, сформованих автоматично шляхом уведення слова-запиту Torschlusspanik у німецькомовних корпусах (усього 1039 фрагментів: CCUL - 101; DWDS - 938).

Відразу слід зазначити, що у випадку, коли самі носії мови не можуть розібратися 3 емоціями та їхніми назвами, то, навпаки, потрібно зробити верифікацію «наївних» даних науковими. Наприклад, нідерландський дослідник Г. Доррен, який не є носієм німецької мови, до того ж, він не $\epsilon$ і психологом, зробив висновок, що протилежною до німецької емоції Neid [заздрість] є специфічна емоція Gönnen [«незаздрість», доброзичливість], лексичного відповідника якій не існує в англійській мові (Dorren 2015). Перевірити його висновок можна за допомогою аналізу фрагментів конкордансів корпусів німецької мови, де знаходимо цьому певне підтвердження, напр.: Das positive Gönnen ist exakt das Gegenwort zum Neid: Man erkennt jemandem neidlos etwas an oder gesteht ihm etwas zu, das für einen selbst auch schön wäre [Позитивна лексема Gönnen («незаздрість») є точним антонімом до слова Neid (заздрість): без заздрості комусь надається висока оцінка за що-небудь або він отримує за щось визнання, що для нього самого було б дуже добре] (DWDS); Mit Neid erreicht man leichter Menschen als mit Gönnen [Із заздрістю легше доберешся до людей, ніж із «незаздрістю»] (CCUL).

Утім, якщо ознайомимося 3 думкою учасників (носіїв німецької мови) спеціальних форумів (див., напр.: German Language; Language Forums), де вже маємо справу з не зовсім «наївним» уявленням про аналізовані емоції, але ще й не повністю фаховим, то вони визначають антонімом до Neid лексему Gunst [доброзичливість], яка є етимологічно спорідненою 3 іменником Gönnen. Причина тут криється в тому, що, на відміну від дієслова gӧnnеn, представники німецькомовних лінгвокультур рідко вживають цей іменник. При цьому деякі учасники цих форумів антонімом до Gunst називають уже не Neid, a Missgunst [недоброзичливість], що $є$ абсолютно логічно з точки зору форми й змісту. Вони також указують на той факт, що не лише лексема Missgunst є близьким синонімом Neid, але і Schadenfreude [зловтіха]. Очевидно, ті емоції, що називають ці синоніми, є дуже близькими, однак, усе ж таки, вони відрізняються певними характеристиками. Прикметно, що протилежними до Schadenfreude є, на їхню думку, аж три емоції Mitgefühl [співчуття; симпатія], Mitleid [жалість; співчуття] та Mitfreude [«співрадість»]. Як бачимо, без залучення надійних словників і довідників, а також наукових джерел із різних галузей знань у таких випадках не обійтися. 
4. Аналіз і результати дослідження. Німецька композита Torschlusspanik калькована в англійську мову в середині минулого століття двома шляхами: (1) зі збереженням німецького правопису (старий і новий варіанти - Torschlußpanik / Torschlusspanik) або (2) з адаптацією до англійського правопису (на початку іменника мала літера - torschlusspanik). Найпоширенішим варіантом є Torschlusspanik (див. Рис. 1). Актуальність цієї композити, за винятком незначного спаду лише в деякі періоди, має тенденцію до різкого зростання. Так, останніми роками різні англійськомовні електронні журнали та газети визначили іiі словом дня (див., напр.: German Word of the Day).

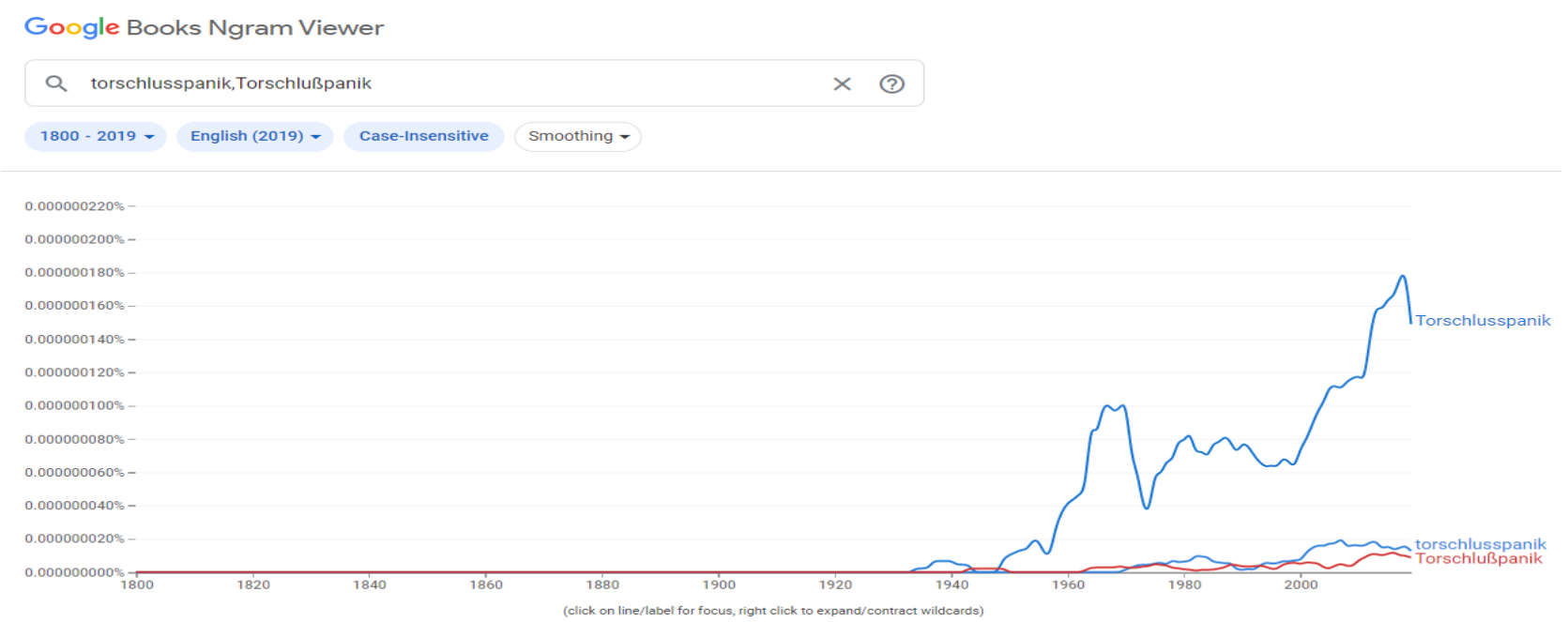

Рис. 1. Графік частотності леми Torschlusspanik (англійський і німецький варіанти написання) за даними Google Books Ngram Viewer; англійська мова; 1800 - 2019 рр.; згладжування $3(\mathrm{GBNV})$

Лексема Torschlusspanik позначає емоцію, яка сама собою не є специфічною для німецькомовних лінгвокультур, оскільки панічний страх через брак часу для реалізації важливих життєвих планів знайомий представникам чи не всіх мовних етносів. Однак своєрідним є те поняття, яке криється за цією лексемою, бо його зміст значною мірою виходить за межі самої емоції. Ширшим це поняття є за рахунок культурних смислів, які воно містить, оскільки не лише похідні, але й навіть базові емоції отримують у процесі соціологізації соціокультурні та етнокультурні смислові відтінки, які впливають на їхнє вираження і сприйняття в тому чи іншому мовному етносі (див., напр.: Elfenbein, Ambady 2002; Friedlmeier et al. 2011).

Оригінальним є метафоричний образ цієї композити - «паніка через закриття воріт» (Tor [ворота] + Schluss [закриття] + Panik [паніка]). Цей образ сягає середньовічних часів, коли міста були водночас фортецями, слугуючи для захисту населення. Вхід у такі міста був зазвичай один - через міські ворота, які закривалися на ніч, тому якщо мандрівник запізнювався, то він мав ночувати за брамою - у незахищеному від небезпеки місці. 
Прикметно, що сама композита Torschlusspanik актуалізувалася лише на початку XX століття (див. Рис. 2), тому її метафоричний образ є стертим не лише для представників «чужих» лінгвокультур, зокрема англосаксонців, але і для сучасних пересічних носіїв німецької мови. Утім, саме загадковий образ закритих воріт сприяв значною мірою поширенню цієї композити в англійськомовному середовищі.

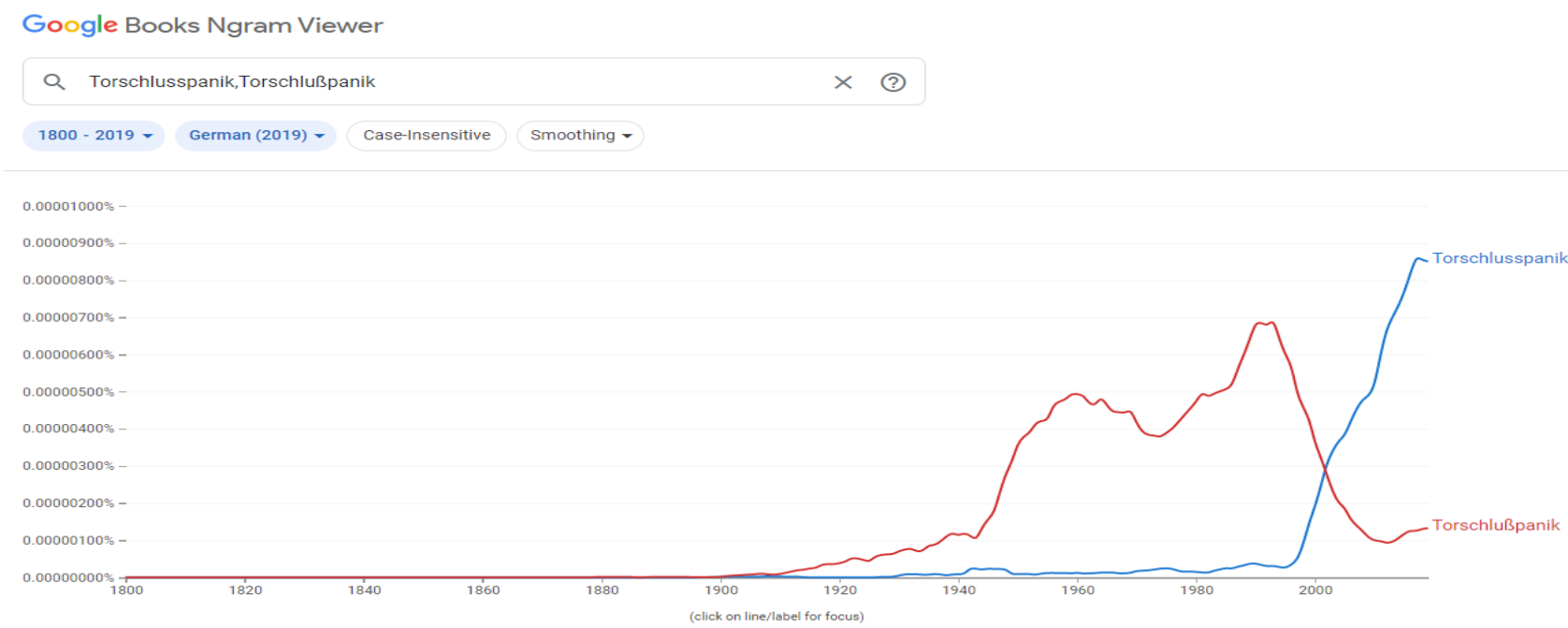

Рис. 2. Графік частотності леми Torschlusspanik (старий і новий правопис) за даними Google Books Ngram Viewer; німецька мова; 1800 - 2019 рр.; згладжування 3 (GBNV)

Аналіз дефініцій лексеми Torschlusspanik в англійськомовному дискурсі - як науковому, так і «наївному» - виявив розбіжності, які свідчать про відсутність адекватного уявлення про справжню сутність цієї емоції, оскільки іiі розуміють то як fear [страх; жах; переляк; побоювання], то як anxiety [тривога; тривожність; неспокій], то як panic [паніка], то як worry [тривога; мука; занепокоєння; клопіт], напр.:

1) Torschlusspanik - the fear that time is running out to act, often regarding a life goal or opportunity [Torschlusspanik - страх, що час для дій добігає кінця; часто про життєву мету або можливість] (Wiktionary);

2) Torschlusspanik describes the anxiety induced by the feeling that time is running out for you to act [Torschlusspanik описує тривогу, яка викликана відчуттям, що час для ваших дій добігає кінця] (German Word of the Day); The German word Torschlusspanik captures a peculiar sort of anxiety... [Німецьке слово Torschlusspanik фіксує особливий вид тривоги...] (Portmann 2018: $761)$;

3) That feeling of panic associated with one's opportunities appearing to run out is called Torschlusspanik [Те відчуття паніки, яке асоціюється із закінченням чиїхось можливостей, називають Torschlusspanik] (Thierry 2021);

4) Torschlusspanik - the worry / fear about diminishing life opportunities as one gets older; also refers to people acting hastily generally when time is running out [Torschlusspanik - тривога / страх щодо скорочення життєвих можливостей, коли хтось старіє; загалом стосується також людей, які діють поспіхом (необдумано), коли закінчується час] (Cope et al. 2019).

Це пов'язано з тим, що ця комплексна емоція містить і страх, і тривогу, і паніку. Таку неоднозначність викликає той факт, що в самих же представників німецьких лінгвокультур Torschlusspanik асоціюється, як мінімум, із трьома емоціями - Angst [(екзистенційний) страх], Furcht [страх; жах; боязнь] та Befürchtung [побоювання], що зафіксовано у словниках і електронних довідниках, напр.:

1) Torschlusspanik - Angst, etwas Entscheidendes zu versäumen [Torschlusspanik (гнітючий, панічний, підсвідомий, моторошний) страх пропустити щось вирішальне] (Duden); 
Torschlusspanik - Angst, eine wichtige Angelegenheit nicht mehr oder zu spät zu erledigen [Torschlusspanik - (гнітючий, панічний, підсвідомий, моторошний) страх не зреалізувати важливу справу або запізно іiі завершити] (DWDS);

2) Torschlusspanik - Furcht, ein wichtiges Lebensziel (aus Altersgründen) nicht mehr zu erreichen, zum Beispiel: Kinder kriegen, Ehepartner finden, bestimmte berufliche Stellung erreichen [Torschlusspanik - страх не зреалізувати важливу життєву мету (через вік), напр.: народити дітей, знайти шлюбного партнера, досягти певних професійних позицій] (Wiktionary);

3) Torschlusspanik - die Befürchtung, dass man etwas Wichtiges versäumt oder dass man für eine Sache zu alt ist [Torschlusspanik - побоювання пропустити щось важливе або бути для якоїсь справи занадто старим] (TFD).

Аналіз наукових і «наївних» дефініцій виявив, що іменники Furcht, а особливо Befürchtung уживаються для характеристики емоції Torschlusspanik значно рідше за Angst. При цьому іменник Panik [паніка], який є одним із компонентів композити Torschlusspanik, можна зустріти лише в окремих випадках, напр.: Torschlusspanik - die Panik der verpassten Gelegenheiten [Torschlusspanik - паніка втрачених можливостей] (Kentridge 2016). Цей висновок узгоджується зі статистичними даними, отриманими шляхом перекладацького аналізу конкордансів у корпусах CCUL i DWDS (див. Табл. 1).

\begin{tabular}{|l|c|c|}
\hline \multicolumn{1}{|c|}{ Koрпус } & CCUL & DWDS \\
\hline $\begin{array}{l}\text { Загалом фрагментів конкордансів із } \\
\text { словом-3апитом Torschlusspanik }\end{array}$ & 101 & 938 \\
\hline Angst & 5 & 32 \\
\hline Furcht & 0 & 7 \\
\hline Befürchtung & 0 & 3 \\
\hline Panik & 0 & 2 \\
\hline
\end{tabular}

Табл. 1. Кількісний показник фрагментів конкордансів, де Torschlusspanik визначається через емоції Angst, Furcht, Befürchtung та Panik

Таблиця 1 чітко демонструє, що в емоційному «букеті» Torschlusspanik домінує метафізичний страх, який позначається в німецькій мові лексемою Angst. Цей специфічний для німецькомовних лінгвокультур вид страху описаний на сьогодні в численних працях психологів, антропологів, культурологів, філософів і лінгвістів (див., напр.: Oster 2012; Wierzbicka 1999), де опрацьовано чіткі критерії розмежування метафізичного (екзистенційного) страху від конкретно-ситуативного. У німецькій мові для цих двох видів страху існують окремі мовні позначення - Angst і Furcht, чого не простежується в низці інших мов (напр., в українській).

Наявність у різних лінгвокультурах різної кількості назв емоції страху пояснюється складністю останньої, оскільки вона демонструє різні вияви перебігу емоційного переживання залежно від ситуації (інтенсивність, фенотипне вираження тощо). Відповідно, кожен із таких виявів може мати окреме позначення у мові. При цьому назви різних видів страху мають здебільшого міжмовні відповідники, бо ця емоція $є$ базовою (універсальною): страх уважається біологічно усвідомленою реакцією, що відіграє значну роль для виживання індивіда, оскільки він подає сигнал про небезпеку та слугує для уникнення останньої. Через те, що страх може з'являтися в різноманітних ситуаціях під різними «масками», його надзвичайно складно «втиснути» в якусь конкретну дефініцію. Так, досі триває гостра дискусія, чи поняття «страх» узагалі можна осмислити, бо, незважаючи на те, що ця емоція (емоційний стан / почуття) відома всім, дуже важко прийти до спільної думки, що ж розуміється під цим поняттям (Becker 2011: 7).

Саме дифузність емоції страху спричинила неоднозначне сприйняття похідної емоції Torschlusspanik навіть носіями німецької мови, оскільки остання асоціюється як із Angst, так і з Furcht (Befürchtung i Panik знаходяться на межі статистичної похибки, тому їх не беремо до 
уваги (див. Табл. 1)). Імовірно, це стало причиною того, що Torschlusspanik перекладається англійською мовою зазвичай лексемою fear, напр.: Torschlusspanik is the fear of being left out in the cold and dark when the gate shuts [Torschlusspanik - це страх залишитися у холоді та темряві, коли закриваються ворота] (Semantic Enigmas); Torschlusspanik is the fear that our life goals and opportunities shrink as time goes by [Torschlusspanik - це страх, що наші життєві цілі та можливості скорочуються із плином часу] (BNC). Однак виникають сумніви щодо коректності такого перекладу, оскільки в цій мові функціонують ще дві лексеми angst (запозичена з німецької мови) та anxiety, зміст яких є, на мою думку, значно ближчим до Torschlusspanik, ніж зміст лексеми fear, пор.:

1) fear - «інтенсивна емоція, що виникає внаслідок небезпеки, болю чи зла, які є для індивіда загрозливими, неминучими або видимими» (NWD: 343);

2) angst - «почуття великої тривоги стосовно певної ситуації або чийогось життя» (Wiktionary);

3) anxiety - «інтенсивна моторошність (страх, жах); смутне передчуття» (NWD: 41).

Лексема fear позначає більш широке поняття страху. Загроза, яка викликає такий страх, має реальне втілення (явища, предмети, тварини тощо), тому в німецькій мові лексичним еквівалентом для fear слушно визначити іменник Furcht (пор. Furcht - сильна емоційна реакція на конкретну, справжню загрозу, наприклад, на отруйну змію (Becker 2011: 9-10)). Власне, Furcht не є тим страхом, який репрезентує емоцію Torschlusspanik, а змістова близькість Furcht i fear у цьому конкретному випадку не має дезорієнтувати фахових перекладачів. До того ж, висновок про те, що Torschlusspanik представляє саме емоція Angst, узгоджується із сучасним розумінням останньої.

Зокрема, феноменальним підгрунтям емоції Angst уважається конфлікт між тілесним (фізичним) стисненням (здавлюванням, звуженням) і спрямованим проти нього спонуканням (імпульсом) до втечі: індивід, з одного боку, відчуває в горлі, грудях і животі здавлювання та звуження (пор. етимологію іменника Angst: грецьк. anchein - «душити; здавлювати; давити»; лат. angor - «стиснення; здавлювання»), із другого боку, - імпульс (поштовх, позив, порив) до втечі, щоб уникнути загрозливої тісноти (звуження). Зрозуміло, що ситуація, яка породжує такий страх, не дозволяє негайної втечі, тому людина перебуває у стані безцільного пориву до руху та дифузного неспокою. Через це обмеження, тобто усвідомлення безвихідності ситуації, посилюється імпульс до втечі, який, у свою чергу, збільшує стиснення. Останнє може інтенсифікувати емоцію Angst до нестерпності. Саме цей антагонізм згаданих двох тенденцій, який не можна усунути, породжує паралізуючу дію Angst. При цьому своєрідною екзистенційною клаустрофобією, одним із видів емоції Angst на екзистенційному рівні є страх перед звуженням (стисненням), недосяжністю чи згаянням можливостей саморозвитку особистості. Це виражається передусім страхом перед закріпленням (фіксацією) та зв’язуванням. Цей страх робить спробу протримати життєві плани якомога довше у підвішеному стані, бо через нього кожне обмеження починає сприйматися як звуження (здавлювання). Одним із таких страхів $\epsilon$ страх перед непрожитим життям і згаяними можливостями, який виникає через усвідомлення того, що наближається смерть або певний період життя добігає кінця (Fuchs, Micali 2013: 11). Ось такий страх німці і називають образною композитою Torschlusspanik. Саме такі переживання знайомі тим індивідам, які хоч раз у житті відчували паніку через брак часу для реалізації чогось життєво важливого.

Тут слід зазначити, що Angst уважається градуйованим феноменом між двома полюсами: дифузним страхом (боязню), з одного боку, та конкретним страхом, що спрямований на певний об'єкт, із другого боку (Demmerling, Landwehr 2007: 80). Це означає, що розмитий i спрямований на майбутнє Angst своєю другою іпостассю, тобто другим полюсом, виявляє характеристики вже іншого виду страху, який позначається в німецькій мові лексемою Furcht (Becker 2011: 9-10). Тобто Angst може трансформуватися у Furcht, але це зовсім не означає, що останній домінує в комплексній емоції Torschlusspanik. 
Викладене вище дає підстави стверджувати, що Torschlusspanik виражається тими емоціями, які в англійській мові позначають лексеми angst [екзистенційний страх; тривога; неспокій; боязнь] та anxiety [неспокій; тривога; боязнь; страх]. 3 огляду на те, що калькована лексема angst є «чужою» в англійськомовному середовищі та, відповідно, непоширеною, функціонуючи переважно в галузі психології (за даними BNC ï частотність складає всього 107, натомість частотність anxiety - 2567), слушною може бути позиція тих науковців, які вважають, що еквівалентним німецькому слову Angst $є$ англійське anxiety (Becker 2011: 9-10), а не angst. Це логічно з тієї точки зору, що лексема angst утратила при калькуванні частину свого значення. I саме ту частину, яка передає специфічність того поняття, що позначає ця лексема. Тому остання відрізняється за змістом від німецької Angst. У деяких дефініціях angst тлумачиться навіть як емоційний хаос або болісний смуток (див., напр.: WD). Натомість anxiety згідно з нозологічною системою DSM-5 (ця «номенклатура» психічних розладів розроблена Американською психіатричною асоціацією) активується загрозою, що є невідомою, імовірною або фактично невизначеною, протиставляючись fear - страху, який спричиняє відома чи зрозуміла загроза (DSM-5). Це означає, що саме лексема anxiety позначає в англійській мові метафізичний страх, тому вона $є$ ближчою за змістом до німецької Torschlusspanik, ніж angst або fear.

Отже, найпоширеніше перекладацьке рішення у випадку опису-перекладу німецької композити Torschlusspanik англійською мовою, коли ця композита передається лексемою fear, $\epsilon$, на мою думку, дещо некоректним, бо в німецькій мові Torschlusspanik - це різновид того страху, який називає слово Angst. Глибше вивчення природи емоційних понять, які позначаються в німецькій мові лексемами Angst, Furcht, Befürchtung і Panik, а в англійській - angst, fear, anxiety i panic, $\epsilon$ тим підгрунтям, яке дає змогу визначити такі пари часткових (коли йдеться про світ емоцій, то про повну міжмовну еквівалентність не доводиться говорити) еквівалентів: Furcht $\approx$ fear; Befürchtung $\approx$ fear; Panik $\approx$ panic; Angst $\approx$ angst / anxiety. Оскільки калькована лексема angst є непоширеною, тобто фактично вона незнайома для значного відсотка носіїв англійської мови, залишається один еквівалент німецькому слову Angst - це anxiety. Відповідно, Torschlusspanik має передаватися-описуватися не лексемою fear, як це простежується нині чи не у більшості випадків, а anxiety, оскільки саме остання може викликати у представників англійськомовних лінгвокультур найадекватніше уявлення про той панічний, тривожний, метафізичний вид страху, який криється за словом Torschlusspanik.

5. Висновки та перспективи дослідження. У пропонованій розвідці, що присвячена виявленню перекладацьких помилок при відтворенні англійською мовою назви специфічного для німецької лінгвокультури поняття «Torschlusspanik», апробовано методику, яка дає змогу уникнути таких помилок. Цю методику визначено як корпуснобазовану, оскільки вона грунтується значною мірою на даних мовних корпусів (частотність, коокуренції, конкорданси). Ïї застосування передбачало три дослідницькі кроки: (1) ідентифікацію перекладацьких помилок, (2) корекцію цих помилок на основі наукових даних та (3) верифікацію наукових даних «наївними» для досягнення максимальної наукової об'єктивності (перекладацький аналіз фрагментів конкордансів, сформованих автоматично шляхом уведення слова-запиту Torschlusspanik у німецькомовних корпусах). За допомогою опрацьованої методики встановлено, що при наявності в англійській мові таких лексем, як angst, fear, anxiety і panic, кожна 3 яких $є$ певною мірою еквівалентною німецькій Torschlusspanik, яка позначає специфічне емоційне поняття, останнє має передаватися-описуватися не лексемою fear, як це простежується нині чи не у більшості випадків, а anxiety, оскільки саме ця лексема може викликати у представників англійськомовних лінгвокультур найадекватніше уявлення про той панічний, тривожний, метафізичний вид страху, який криється за словом Torschlusspanik.

Перспектива пропонованого дослідження вбачається у подальшому удосконаленні аналітичного інструментарію апробованої методики. 


\section{Література}

Мізін, Костянтин. «“Німецька затишність” як риса національного характеру: зіставнолінгвокультурологічний аналіз». Лінгвістичні студіï / Linguistic Studies 36, 2018: 61-67. Print.

[Mizin, Kostyantyn. "Nimets'ka zatyshnist"” yak rysa natsional'noho kharakteru: zistavnolinhvokul'turolohichnyy analiz». Linhvistychni studiyi / Linguistic Studies 36, 2018: 61-67. Print.]

Becker, Eni. Angst. München \& Basel: Ernst Reinhardt Verlag, 2011. Print.

Cope, A., Oattes, G., Hussey, W. Zest: How to Squeeze the Max out of Life. Oxford: Capstone, 2019. Print.

Demmerling, Ch., Landweer, H. Philosophie der Gefühle. Von Achtung bis Zorn. Stuttgart: Metzler, 2007. Print.

Dorren, Gaston. Lingo: Around Europe in Sixty Languages. New York: Atlantic Monthly Press, 2015. Print.

Elfenbein, H. A., Ambady, N. «On the Universality and Cultural Specificity of Emotion Recognition: A Meta-analysis». Psychological Bulletin 128(2), 2002: 203-235. Web. 07 Jan. 2021.

Friedlmeier, W., Corapci, F., Cole, P. M. «Socialization of Emotions in Cross-cultural Perspective». Social and Personality Psychology Compass 5(7), 2011: 410-427. Web. 06 Jan. 2021.

Fuchs, Th., Micali, S. «Phänomenologie der Angst». [In:] L. Koch (Hrsg.) Angst. Ein interdisziplinäres Handbuch. Stuttgart \& Weimar: Metzler, 2013, 61-71. Web. 14 Jan. 2021.

Levenson, R. W. «Basic Emotion Questions». Emotion Review 3(4), 2011: 379-386. Web. 01 Jan. 2021.

Mizin, K., Letiucha, L., Petrov, O. «Deutsche linguokulturelle Konzepte im Lichte der germanisch-ostslawischen Kontraste: Methode zur Feststellung von spezifischen bzw. einzigartigen Bedeutungen». Germanoslavica 30(1), 2019: 49-70. Print.

Mizin, K., Letiucha, L. «The Linguo-cultural Concept TORSCHLUSSPANIK as the Representative of Ethno-specific Psycho-emotional State of Germans». Психолінгвістика. Психолингвистика. Psycholinguistics 25(2), 2019: 234-249. Print.

Mizin, K., Ovsiienko, L. «The German Linguo-cultural Concept SCHADENFREUDE in Crosscultural Perspective: A Corpus-based Approach». Lege Artis. Language Yesterday, Today, Tomorrow. The Journal of University of SS Cyril and Methodius in Trnava V(1), 2020: 143-184. Web. 07 Jan. 2021.

Oster, Ulrike. "“Angst" and "Fear" in Contrast: A Corpus-based Analysis of Emotion Concepts». [In:] M. Brdar, I. Raffaelli, Ž. M. Fuchs (Eds.) Cognitive Linguistics between Universality and Variation. Newcastle upon Tyne: Cambridge Scholars Publishing, 2012, 327-355. Web. 14 Jan. 2021.

Plutchik, Robert. «A General Psychoevolutionary Theory of Emotion». [In:] R. Plutchik \& H. Kellerman (Eds.) Emotion: Theory, Research and Experience, Theories of Emotion. New York: Academic Press, 1980, Vol. 1, 3-33. Web. 15 Jan. 2021.

Plutchik, R., Conte, H. R. (Eds.). Circumplex Models of Personality and Emotions. Washington, DC: American Psychological Association, 1997. Web. 07 Jan. 2021.

Portmann, John. «Left Behind: Torschlusspanik and Anxiety». Philosophia 46(3), 2018:761-770. Web. 01 Jan. 2021.

Schwarz-Friesel, Monika. «Sprache, Kognition und Emotion: Neue Wege in der Kognitionswissenschaft». [In:] H. Kämper, L. M. Eichinger (Hrsg.) Sprache - Kognition - Kultur. Sprache zwischen mentaler Struktur und kultureller Prägung. Berlin \& New York: de Gruyter, 2008, 277301. Web. 07 Jan. 2021.

Wierzbicka, Anna. Emotions Across Languages and Cultures: Diversity and Universals. Cambridge: Cambridge University Press, 1999. Print.

\section{Використані джерела}

АУС. Англійсько-українські словники <https://e2u.org.ua/s?w> 02.01.2021.

[AUS. Anglìjs'ko-ukraïns'kì slovniki <https://e2u.org.ua/s?w>02.01.2021.]

BNC. British National Corpus <http://www.natcorp.ox.ac.uk/> 07.01.2021. 
CCUL. Corpora Collection of University Leipzig <http://corpora.informatik.uni-leipzig.de> 07.01.2021.

DSM-5. Diagnostic and Statistical Manual of Mental Disorders <https://www.psychiatry.org/psychiatrists/practice/dsm> 06.01.2021.

Duden <https://www.duden.de/rechtschreibung/Torschlusspanik> 14.01.2021.

DWDS. Digitales Wörterbuch der deutschen Sprache <http://www.dwds.de/ressourcen/korpora/> 13.01.2021.

GBNV. Google Books Ngram Viewer <https://books.google.com/ngrams> 15.01.2021.

German Language: Looking for the Opposite of Schadenfreude <https://german.stackexchange.com/questions/53131/looking-for-the-opposite-of-schadenfreude> 26.12.2020.

German Word of the Day: Die Torschlusspanik <https://www.thelocal.de/20181001/word-of-theday-torschlusspanik> 26.12.2020.

Kentridge, William. «Erfolg ist immer ein Desaster»<https://www.tagesspiegel.de/kultur/williamkentridge-im-interview-torschlusspanik-ist-ein-tolles-deutsches-wort/13570998-3.html>

31.12.2020.

Language Forums <https://forum.wordreference.com/threads/schadenfreude-missgunst.2847655/> 26.12.2020.

NWD. New Webster's Dictionary and Thesaurus of the English Language. Danbury, CT: Lexicon Publications, 1993. Print.

Semantic enigmas <https://www.theguardian.com/notesandqueries/query/0,5753,-21634,00.html> 13.01.2021.

TFD. The Free Dictionary <https://de.thefreedictionary.com/Torschlusspanik> 14.01.2021.

Thierry, Guillaume. The power of language: we translate our thoughts into words, but words also affect the way we think <https://theconversation.com/the-power-of-language-we-translate-ourthoughts-into-words-but-words-also-affect-the-way-we-think-111801>07.01.2021.

WD. WikiDiff <https://wikidiff.com/angst/fear> 26.12.2020.

Wiktionary <https://en.wiktionary.org/wiki/Torschlusspanik> 26.12.2020.

\section{AVOIDING TRANSLATION MISTAKES WHILE RENDERING THE NAMES OF «ALIEN» EMOTIONS INTO ENGLISH: CORPUS-BASED METHODOLOGY \\ Kostiantyn Mizin}

Head of Department of Foreign Philology, Translation and Teaching Methodology, SHEI «Pereiaslav-Khmelnytskyi Hryhorii Skovoroda State Pedagogical University», Pereiaslav, Ukraine

\section{Abstract}

Background: Regarding the difficulties a translator confronts with while rendering emotions, one should mention at least three cases when a translator needs to reinforce the correctness of the choice as to a counterpart (an equivalent word) of the target language by means of scientifically valid conclusions: 1) if there are doubts as to accuracy of the lexical counterpart in the target language that denotes a certain emotional notion fixed by bilingual dictionaries; 2 ) if lexical counterparts are absent in dictionaries at all; 3) if not only dictionary counterparts are absent but also an emotional notion itself is irrelevant (not typical) for the target linguoculture.

Purpose: The purpose of the study is (1) to reveal translation mistakes while rendering the name of the notion «Torschlusspanik» specific to the German linguoculture into English and (2) to develop a method that enables to avoid such mistakes. This method intends to use the data of language corpora (frequency, co-occurrents, and concordances).

Results: With the help of the method it was defined that the emotional notion «Torschlusspanik» should be rendered or described not by the lexeme fear, as it can be observed nowadays in most cases, but by anxiety since the latter can give the representatives of the Englishspeaking linguocultures the most adequate idea about panic, disturbing and metaphysical kind of fear represented by the compound noun Torschlusspanik. 
Discussion: The most commonly used translation decision as to the German compound noun Torschlusspanik while rendered by the lexeme fear into English is somewhat irrelevant since Torschlusspanik in German is a kind of the particular fear represented by the word Angst. A deeper study of the nature of the emotional notions denoted in German by lexemes Angst, Furcht, Befürchtung and Panik, and in English by angst, fear, anxiety and panic is the basis that makes it possible to determine such pairs of partial equivalents as (full equivalence is not worth speaking about): Furcht $\approx$ fear; Befürchtung $\approx$ fear; Panik $\approx$ panic; Angst $\approx$ angst / anxiety.

Keywords: translation, translation mistake, emotion, emotional notion, corpus-based methodology.

\section{Vitae}

Kostiantyn Mizin is Doctor of Philology, Professor, Head of Department of Foreign Philology, Translation and Teaching Methodology, SHEI "Pereiaslav-Khmelnytskyi Hryhorii Skovoroda State Pedagogical University". His areas of research interests include contrastive linguoculturology, phraseology, contrastive conceptology, cognitive linguistics, contrastive linguistics.

Correspondence: kmizin@i.ua

Надійшла до редакції 25 березня 2021 року Рекомендована до друку 8 квітня 2021 року

Ганна Ситар

ORCID: orcid.org 0000-0001-8806-8322

Анастасія Мартинович (Вдовиченко)

ORCID: orcid.org 0000-0002-5254-470X

DOI 10.31558/1815-3070.2021.41.35

УДК 811.161.2'28'33(477.44):004.416.6

\section{ЕКСПЕРТНА СИСТЕМА АНАЛІЗУ МОВЛЕННЯ МЕШКАНЦІВ МІСТА ГНІВАНЬ: ДОСВІД СТВОРЕННЯ}

Запропоновано лінгвістичну частину експертної системи аналізу діалектного мовлення, описано етапи ї̈ створення. Виділено фонетичні та морфологічні риси говірки міста Гнівань Тиврівського району Вінницької області. Схарактеризовано процес створення словника говірки. Подано опис основних компонентів експертної системи аналізу мовлення мешканиів міста Гнівань.

Ключові слова: аналіз мовлення, говірка, діалект, експертна система, прикладна лінгвістика, словник.

Постановка проблеми та їі актуальність. Експертні системи є одним із важливих напрямів досліджень у межах штучного інтелекту, вони мають великий потенціал для вирішення різних практичних завдань, у тому числі у сфері аналізу мови та мовлення.

На сучасному етапі розвитку штучного інтелекту створюють різні програми для аналізу літературної мови. Однак, цього, на жаль, ще не можна сказати про українське діалектне мовлення, що є одним із найцінніших джерел для вивчення динамічних процесів у мові. Тому створення експертної системи аналізу мовлення мешканців міста Гнівань $\epsilon$ важливим кроком у застосуванні підходів штучного інтелекту для вивчення діалектного мовлення.

Аналіз досліджень. Експертна система - це комп'ютерна програма, що оперує знаннями в певній предметній галузі для створення рекомендацій або для розв'язання відповідних проблем (Джексон 2001: 12). Вона покликана частково замінити собою людину-фахівця, 